\title{
Kajakos és kenus élsportolók bal és jobb kamrai analízise 3D echokardiográfia segítségével
}

\author{
Ujvári Adrienn, Komka Zsolt, Kántor Zoltán, Lakatos Bálint Károly, \\ Tokodi Márton, Doronina Alexandra, Babity Máté, Bognár Csaba, \\ Kiss Orsolya, Merkely Béla, Kovács Attila
}

Semmelweis Egyetem, Városmajori Szív- és Érgyógyászati Klinika, Budapest

Levelezési cím: Dr. Kovács Attila, 1122 Budapest, Városmajor utca 68. e-mail: attila.kovacs@cirg.hu

\begin{abstract}
Célkitűzés: Sportolókban a keringési csúcsszükséglet biztosításához a szívizomzat és a kardiovaszkuláris szabályozó rendszerek komplex változásai szükségesek, amelyek jellegzetes morfológiai és funkcionális eltéréseket okoznak a szívben. A 3D echokardiográfia a sportszív volumetriás analízisében és miokardiális mechanikájának megértésében is kiemelkedően fontos modalitás lehet. Vizsgálatunk célja kajakos és kenus élsportolók bal és jobb kamrai 3D echokardiográfiás analízise és sportszívük egészséges, nem sportoló önkéntesek szívével való összehasonlítása volt.

Betegek és módszerek: 11 kajakos, illetve kenus férfi élsportolót vizsgáltunk, köztük számos olimpikonnal, világ-, Európa- és/vagy országos bajnokkal. Kontrollcsoportként 10, rendszeresen nem sportoló, egészséges önkéntest válogattunk. A hagyományos 2D echokardiográfiás protokollon felül bal vagy jobb kamrára optimálizált 3D felvételeket rögzítettünk apicalis ablakból. A bal- és jobb kamrai volumenek, ejekciós frakció, valamint a longitudinális strain számításához dedikált 3D szoftvereket alkalmaztunk.

Eredmények: A bal kamrai végdiasztolés, végszisztolés és verővolumen, valamint az izomtömeg egyaránt szignifikánsan nagyobb volt az élsportolókban a kontrollokhoz viszonyítva. Az ejekciós frakció normál tartományban volt, azonban értéke alacsonyabb volt a kontrollcsoporthoz viszonyítva. Ezzel párhuzamosan a bal kamrai globális longitudinális strain is szignifikánsan alacsonyabb volt sportolókban. A jobb kamrai végdiasztolés, végszisztolés és verővolumen szintén szignifikánsan magasabb, az ejekciós frakció pedig alacsonyabb volt élsportolókban. Mind a szeptális, mind a szabad fali longitudinális strain értéke alacsonyabbnak bizonyult az élsportolói csoportban.

Következtetések: Kajakos és kenus élsportolókban jelentős bal- és jobb kamrai dilatáció figyelhető meg. A nyugalmi bal- és jobbkamra-funkció, mind ejekciós frakció, mind longitudinális strain tekintetében megtartott, azonban nem sportoló egészséges személyekhez képest csökkent.
\end{abstract}

Kulcsszavak: sportszív, 3D echokardiográfia, longitudinális strain

\section{D echocardiographic analysis of elite kayak/canoe athletes}

Aims: Regular, vigorous physical exercise resuls in complex cardiovascular adaptation including changes in cardiac structure and function (athlete's heart). 3D echocardiography represents a novel and promising modality for a better understanding of the volumetric and myocardial mechanical changes of the athlete's heart. Our aim was to characterize cardiac morphology and function of elite kayak or canoe athletes using 3D echocardiography and to compare with healthy, sedentary volunteers.

Patients and methods: Eleven elite kayak or canoe athletes including numerous olympic-, world-, European- or national champions were enrolled. Ten healthy, sedentary volunteers served as control group. Beyond standard 2D echocardiographic protocol, 3D full volume acquisitions were acquired from apical approach. Left and right ventricular volumes, ejection fraction and longitudinal strain values were measured by dedicated 3D software environment.

Results: Left ventricular end-diastolic, end-systolic and stroke volumes and mass were higher among athletes. Left ventricular ejection fraction was preserved, however, was lower compared to the control group. Left ventricular global longitudinal strain was also lower in the athletes. In parallel, right ventricular end-diastolic, end-systolic and stroke volumes were higher, ejection fraction was lower among athletes. Correspondingly, both right ventricular free-wall and septal longitudinal strain were lower in athletes.

Conclusions: Athlete's heart of elite kayak or canoe athletes is characterized by significantly increased left and right ventricular volumes. At rest, the systolic function of both ventricles is maintained, however, ejection fraction and longitudinal strain values are lower compared to healthy controls.

Keywords: athlete's heart, 3D echocardiography, longitudinal strain 


\section{Bevezetés}

Az élsportolók extrém fizikai terhelése szélsőséges hemodinamikai változásokat igényel: a nyugalmi perctérfogat öt-hatszoros növekedése, és/vagy a szisztolés vérnyomás igen jelentős emelkedése lehet szükséges maximális erőkifejtés esetén. Mindezt a szívizomzat a verőtérfogat 25-50\%-os emelkedésével és a szívfrekvencia akár négy-ötszörösére fokozódásával éri el. A keringési csúcsszükséglet biztosításához a szívizomzat és a kardiovaszkuláris szabályozó rendszerek komplex változásai szükségesek, amelyek jellegzetes morfológiai és funkcionális eltéréseket okoznak az egészséges egyénekhez viszonyítva (fiziológiás remodelláció - sportszív) (1). A szívizomzat tömegének növekedése a kardiális adaptáció talán legjellegzetesebb mozzanata. A Morganroth és munkatársai által publikált több mint 40 éves hipotézis (2), ami alapgondolatában máig érvényesnek tekinthető, a terhelés típusa alapján két morfológiai típusra osztja a fiziológiás remodellációt: az izotóniás terhelés (más néven dinamikus terhelés) esetén a perctérfogat tartós emelkedése jellemző megtartott vagy csökkent perifériás vaszkuláris rezisztencia mellett. Mindez a szívüregek volumenterhelésével (preload) jár, ami a kamrák térfogatának növekedését indukálja megtartott vagy enyhe falvastagság-növekedés mellett (excentrikus hipertrófia). Az izometriás (más néven statikus) terhelés esetén a perctérfogat legfeljebb enyhe emelkedése mellett a perifériás vaszkuláris rezisztencia jelentősen növekszik, ami a kamrák nyomásterhelését (afterload) okozza, és ez a kamrai falvastagság (dominánsan a bal szívfélben) növekedésével jár megtartott kamrai volumenek mellett (koncentrikus hipertrófia). Terhelés hatására a jobb szívfélben is változások jönnek létre: dinamikus terhelésű sportolókban a bal kamra dilatációjával párhuzamosan a jobb kamra térfogatának az emelkedése is észlelhető, kevésbé kifejezett hipertrófia mellett $(3,4)$. Mindazonáltal a jobb kamrai geometriáról és funkcióról jóval kevesebb adat áll rendelkezésünkre, klinikai relevanciája ellenére (5).

A 3D echokardiográfia a sportszív volumetriás analízisében és miokardiális mechanikájának megértésében is kiemelkedően fontos modalitás lehet. A geometriai képletektől mentes, valós térbeli mérések jóval pontosabb és reprodukálhatóbb paramétereket eredményeznek, ez által az edzés indukált bal és jobb kamrai morfológiai és funkcionális remodelling is részletesebben elemezhetővé válhat.

Jelen vizsgálatunk célja kajakos és kenus élsportolók bal és jobb kamrai 3D echokardiográfiás analízise és sportszívük egészséges, nem sportoló önkéntesek szívével való összehasonlítása volt.

\section{Módszerek}

11 kajakos, illetve kenus férfi élsportolót vizsgáltunk, köztük számos olimpikonnal, világ-, Európa- és/vagy országos bajnokkal. Regisztráltuk anamnesztikus és antropometriai adataikat, fizikális vizsgálat, vérnyomásmérés történt, EKG-t rögzítettünk. Kizárási kritériumot képezett bármilyen korábbi ismert kardiális megbetegedés (kivéve a kezelt hipertónia), jelentősebb billentyűbetegség jelenléte, illetve a fizikális vizsgálat, az EKG- vagy a szívultrahang-vizsgálat által felvetett és későbbi szív MR-vizsgálattal ki nem zárt patológiás eltérés jelenléte. Kontrollcsoportként életkorban illesztett, egészséges, rendszeresen nem sportoló férfi önkénteseket vizsgáltunk ( $n=10)$. A testfelszínt (BSA) a Mosteller-formulával számítottuk (6).

A transztorakális echokardiográfiás vizsgálatot bal oldalfekvésben, folyamatos EKG-regisztrálás mellett végeztük Philips iE33 ultrahang-rendszerrel, S5-1 és X5-1 transzducerek segítségével (Philips Healthcare, Best, Hollandia). Az utóelemzéshez az adatokat TomTec ImageArena platformon archiváltuk (TomTec Imaging GmbH, Unterschleissheim, Németország). A bal kamrai végdiasztolés és végszisztolés átmérőket, a végdiasztolés szeptális és hátsó fali vastagságokat 2D képeken határoztuk meg 2D vezérelt M-mód segítségével közvetlenül a mitralis vitorlák koaptációjának szintje alatt (7). Az M-mód adatokból a Devereux-formulával számítottunk bal kamrai izomtömeget (8). A relatív falvastagságot a szeptális és hátsó fali vastagság összege és a végdiasztolés bal kamrai átmérő hányadosaként számítottuk. A jobb kamrai basalis és mid átmérőket, valamint a jobb kamrai hosszanti átmérőt jobb kamrára fókuszált apicalis négyüregi képen, végdiasztoléban mértük. A tricuspidalis annulus szisztolés elmozdulását (TAPSE), mint a jobb kamra longitudinális funkció hagyományos paraméterét, M-mód segítségével mértük. A bal és jobb pitvari végszisztolés (maximális) volument „monoplane” Simpson-módszerrel határoztuk meg. A mitralis beáramlást PW-Dopplerrel profiloztuk a mitralis vitorla hegyének szintjében. Szöveti Doppler-képalkotás (PW TDI) segítségével mértük a tricuspidalis és a mitralis anulus elmozdulásának sebességét apicalis négyüregi képen szisztoléban és diasztoléban (a mitralis anulus esetén laterálisan és szeptálisan egyaránt). Az esetleges billentyübetegségek kvantifikálását az aktuális irányelvek szerint végeztük (9).

A hagyományos 2D protokollon felül bal vagy jobb kamrára optimálizált 3D felvételeket vettünk fel apicalis ablakból. A megfelelő térbeli- és időbeli felbontás érdekében 4 vagy 6 szívciklusból, EKG kapuzva rekonstruált „full volume” felvételeket rögzítettünk (1. ábra). A bal kamrai végdiasztolés, végszisztolés és verővolumenek, valamint az ejekciós frakció méréséhez TomTec 4D LV-Analysis 3 szoftvert használtunk. A szoftver segítségével az epikardiális bal kamrai kontúr is meghatározható, így valós, 3D volumetrián alapuló bal kamrai izomtömeg mérésre van lehetőség. A rekonstruált endokardiális felszínből a szoftver kiszámítja a globális longitudinális és cirkumferenciális straint is. A jobb kamrai végdiasztolés, végszisztolés és verővolume- 


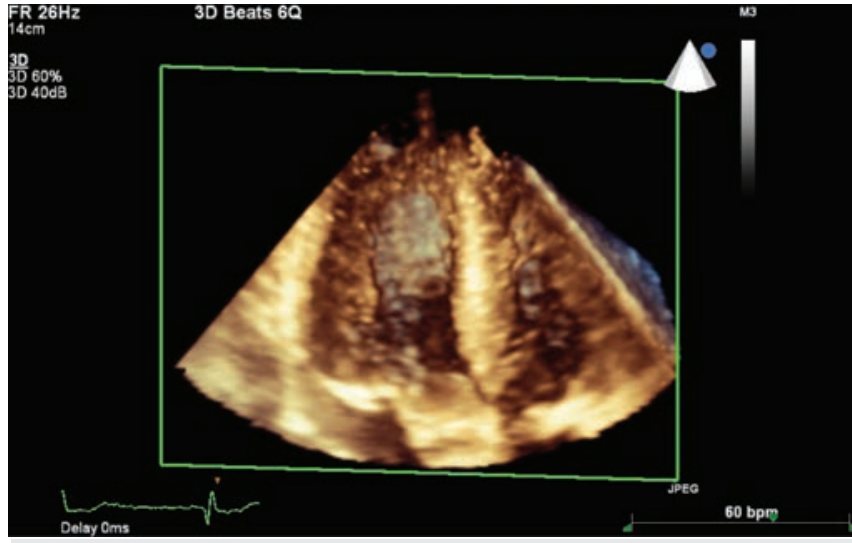

1. ÁBRA. Transztorakális „full volume” 3D felvétel 6 szívciklusból rekonstruálva (volume rendering megjelenítés, csúcsi ablakból)

nek, valamint az ejekciós frakció méréséhez TomTec 4D RV-Function 2 szoftvert használtunk. A szoftver a 3D-ből standard módon derivált apicalis négyüregi képen automatikusan méri a "fractional area change"-t (FAC), valamint a szeptális kontúrból kiszámítja a szeptális longitudinális strain, a szabad fali kontúrból pedig a szabad fali longitudinális straint.

Adatainkat átlag \pm standard deviációként tüntettük fel. A változók normalitását Shapiro-Wilk-teszttel vizsgáltuk. A két csoport értékeinek összehasonlítását a Student-féle t-, illetve Mann-Whitney U-teszttel végeztük. A p<0,05 értékeket tekintettük statisztikailag szignifikánsnak.

\section{Eredmények}

A beválasztási kritériumoknak megfelelően az élsportolók és kontrolljaik életkorban nem különböztek szignifikánsan (1. táblázat). Magasságuk, testsúlyuk és

1. TÁBLÁZAT. A sportolói és a kontrollcsoport alapvető demográfiai és hemodinamikai paramétereinek összehasonlítása

\begin{tabular}{|c|c|c|c|}
\hline & Sportoló & Kontroll & $\mathbf{p}$ \\
\hline Betegszám (n) & 11 & 10 & \\
\hline Életkor (év) & $29 \pm 5$ & $27 \pm 4$ & 0,429 \\
\hline Testmagasság (cm) & $182 \pm 10$ & $176 \pm 10$ & 0,154 \\
\hline Testsúly (kg) & $80 \pm 8$ & $86 \pm 17$ & 0,295 \\
\hline Testfelszín $\left(\mathrm{m}^{2}\right)$ & $2,02 \pm 0,13$ & $2,02 \pm 0,25$ & 0,930 \\
\hline $\begin{array}{l}\text { Szisztolés vérnyomás } \\
\text { (Hgmm) }\end{array}$ & $140 \pm 10$ & $118 \pm 10$ & 0,001 \\
\hline $\begin{array}{l}\text { Diasztolés vérnyomás } \\
\text { (Hgmm) }\end{array}$ & $76 \pm 9$ & $66 \pm 4$ & 0,018 \\
\hline Szívfrekvencia (/perc) & $54 \pm 7$ & $64 \pm 13$ & 0,033 \\
\hline $\begin{array}{l}\text { Edzéssel töltött órák } \\
\text { száma (/hét) }\end{array}$ & $19 \pm 4$ & & \\
\hline $\begin{array}{l}\text { Versenyszerü edzéssel } \\
\text { töltött évek száma }\end{array}$ & $19 \pm 4$ & & \\
\hline
\end{tabular}

testfelszínük is azonos volt. Vérnyomás tekintetében a sportolók szignifikánsan magasabb szisztolés és diasztolés értékekkel rendelkeztek. Szívfrekvenciájuk a várakozásoknak megfelelően azonban alacsonyabb volt. A vizsgált élsportolók átlagosan több mint 19 éve sportoltak aktívan és heti átlagosan több mint 19 órát edzettek a vizsgálatuk időpontjában (1. táblázat).

Hagyományos szívultrahangos paramétereiket tekintve, mind a szeptális, mind a hátsó fali végdiasztolés falvastagság szignifikánsan magasabb volt az élsportolókban (2. táblázat). A bal kamrai végdiasztolés átmérő szintén nagyobb volt, a végszisztolés átmérő azonban

2. TÁBLÁZAT. A sportolói és a kontrollcsoport hagyományos echokardiográfiás paramétereinek összehasonlítása

\begin{tabular}{|c|c|c|c|}
\hline & $\begin{array}{l}\text { Sportoló } \\
(n=11)\end{array}$ & $\begin{array}{c}\text { Kontroll } \\
(n=10)\end{array}$ & $\mathbf{p}$ \\
\hline IVSd (mm) & $13,4 \pm 2,0$ & $10,5 \pm 1,8$ & 0,002 \\
\hline LVPWd (mm) & $11,9 \pm 1,2$ & $8,8 \pm 1,9$ & $<0,001$ \\
\hline LVIDd (mm) & $52,7 \pm 3,7$ & $48,6 \pm 4,6$ & 0,039 \\
\hline LVIDs (mm) & $34,5 \pm 3,1$ & $32,3 \pm 7,0$ & 0,348 \\
\hline LV mass Devereux (g) & $340 \pm 58$ & $207 \pm 49$ & $<0,001$ \\
\hline Relatív falvastagság & $0,48 \pm 0,07$ & $0,40 \pm 0,09$ & 0,030 \\
\hline RV bazális átmérő (mm) & $46,5 \pm 3,8$ & $39,1 \pm 2,5$ & $<0,001$ \\
\hline RV középső átmérő (mm) & $40,4 \pm 2,5$ & $30,9 \pm 3,6$ & $<0,001$ \\
\hline RV-hossz (mm) & $89 \pm 6$ & $79 \pm 8$ & 0,002 \\
\hline TAPSE $(\mathrm{mm})$ & $25,5 \pm 4,3$ & $24,8 \pm 2,6$ & 0,668 \\
\hline LA-volumen (ml) & $85 \pm 20$ & $58 \pm 14$ & 0,002 \\
\hline LA-volumen index $\left(\mathrm{ml} / \mathrm{m}^{2}\right)$ & $39 \pm 16$ & $28 \pm 6$ & 0,043 \\
\hline RA-volumen (ml) & $82 \pm 22$ & $47 \pm 13$ & $<0,001$ \\
\hline RA-volumen index $\left(\mathrm{ml} / \mathrm{m}^{2}\right)$ & $41 \pm 10$ & $23 \pm 6$ & $<0,001$ \\
\hline Mitralis E-hullám (m/s) & $0,8 \pm 0,2$ & $0,9 \pm 0,1$ & 0,201 \\
\hline Mitralis A-hullám (m/s) & $0,5 \pm 0,1$ & $0,6 \pm 0,1$ & 0,083 \\
\hline Mitralis E/A-arány & $1,8 \pm 0,4$ & $1,7 \pm 0,4$ & 0,570 \\
\hline Decelerációs idő (ms) & $187 \pm 29$ & $181 \pm 41$ & 0,682 \\
\hline Mitralis laterális anulus s' $(\mathrm{cm} / \mathrm{s})$ & $11 \pm 1$ & $11 \pm 2$ & 0,507 \\
\hline $\begin{array}{l}\text { Mitralis laterális anulus e' } \\
(\mathrm{cm} / \mathrm{s})\end{array}$ & $16 \pm 3$ & $18 \pm 4$ & 0,406 \\
\hline $\begin{array}{l}\text { Mitralis laterális anulus a' } \\
(\mathrm{cm} / \mathrm{s})\end{array}$ & $7 \pm 1$ & $8 \pm 1$ & 0,105 \\
\hline $\begin{array}{l}\text { Mitralis szeptális anulus s' } \\
(\mathrm{cm} / \mathrm{s})\end{array}$ & $9 \pm 2$ & $9 \pm 2$ & 0,983 \\
\hline $\begin{array}{l}\text { Mitralis szeptális anulus e' } \\
(\mathrm{cm} / \mathrm{s})\end{array}$ & $12 \pm 4$ & $13 \pm 3$ & 0,577 \\
\hline $\begin{array}{l}\text { Mitralis szeptális anulus a' } \\
(\mathrm{cm} / \mathrm{s})\end{array}$ & $7 \pm 2$ & $8 \pm 2$ & 0,076 \\
\hline Átlagos E/e' & $5,2 \pm 1,2$ & $5,4 \pm 1,2$ & 0,778 \\
\hline Tricuspidalis anulus s' (cm/s) & $14 \pm 2$ & $13 \pm 3$ & 0,392 \\
\hline Tricuspidalis anulus e' $(\mathrm{cm} / \mathrm{s})$ & $14 \pm 3$ & $15 \pm 3$ & 0,770 \\
\hline Tricuspidalis anulus a' (cm/s) & $10 \pm 2$ & $10 \pm 3$ & 0,760 \\
\hline
\end{tabular}

LV: bal kamrai, RV: jobb kamrai, LA: bal pitvari, RA: jobb pitvari, „d”: végdiasztolés, „S": végszisztolés, IVS: interventrikuláris szeptum, PW: hátsó fal, ID: belső átmérő, TAPSE: a tricuspidalis anulus szisztolés elmozdulása 
nem különbözött a két csoport között. Ennek megfelelően a Devereux-formulával számított bal kamrai izomtömeg jelentősen emelkedett értékeket eredményezett sportolók esetén. A relatív falvastagság-emelkedés alapján a sportolóknál koncentrikus típusú bal kamrai hipertrófia volt kimutatható.

A jobb kamrai konvencionális paraméterek tekintetében hasonló jellegű eltéréseket figyelhetünk meg (2. táblázat). Mind a bazális, mind a mid, mind pedig a jobb kamrai hosszanti átmérő szignifikánsan nagyobb volt a sportolókban. Az M-mód technikával meghatározott TAPSE-érték nem mutatott különbséget a két csoport között.

Mind a bal, mind pedig a jobb pitvar szignifikánsan nagyobb volt az élsportolói csoportban, testfelszínre indexált értékként is. A diasztolés funkció tekintetében nem volt különbség sem a mitralis beáramlás korai, sem atriális hulláma esetén, hasonlóképpen nem különbözött az E/A-arány és a decelerációs idő. Nem találtunk különbséget sem a mitralis laterális, sem a szeptális anulus TDI-értékek tekintetében, az Ele' arány sem különbözött. A jobb kamra PW TDI-értékek sem különböztek a két csoport között (2. táblázat).

A 3D echokardiográfia segítségével nyert paramétereket a 3. táblázat tartalmazza. A bal kamrai végdiasztolés, végszisztolés és verővolumen egyaránt szignifikánsan nagyobb volt az élsportolókban a kontrollokhoz viszonyítva, az értékek testfelszínre való indexálása után is. A bal kamrai EF szignifikánsan alacsonyabbnak bizonyult sportolókban, azonban értékei abszolút értékben megtartott szisztolés funkciót jeleztek nyugalomban. A 3D echokardiográfiával meghatározott bal kamrai izomtömeg szintén emelkedett értékeket mutatott élsportolókban (BSA-ra indexáltan is), abszolút értékben azonban jóval alacsonyabb értékeket mértünk a Devereux-formulához képest. Érdekes módon mind a globális longitudinális, mind a globális cirkumferenciális strain szignifikánsan alacsonyabb volt sportolókban (2. ábra).

A bal kamrához hasonlóan, a 3D echokardiográfiával mért jobb kamrai végdiasztolés, végszisztolés és verővolumen szintén szignifikánsan magasabb volt élsportolókban (3. táblázat). Sportolókban a jobb kamrai EF értéke a kontrollokhoz viszonyítva szintén alacsonyabb volt, alacsony-normál tartományban mozgott (3. ábra). A 3D echokardiográfia segítségével számított FAC nem különbözött a két csoport között. Mind a szeptális, mind a szabad fali longitudinális strain értéke alacsonyabbnak bizonyult az élsportolói csoportban (3. táblázat).

\section{Megbeszélés}

Élsportolóink kardiológiai és echokardiográfiás vizsgálata a még napjainkban sem elegendő rendelkezésre álló adat miatt továbbra is kihívás. Jelen vizsgálatunkkal részletes jellemzést adtunk kajakos és kenus, világelitbe tartozó sportolóink bal és jobb kamrai morfológiájáról és funkciójáról 3D echokardiográfia segítségével.
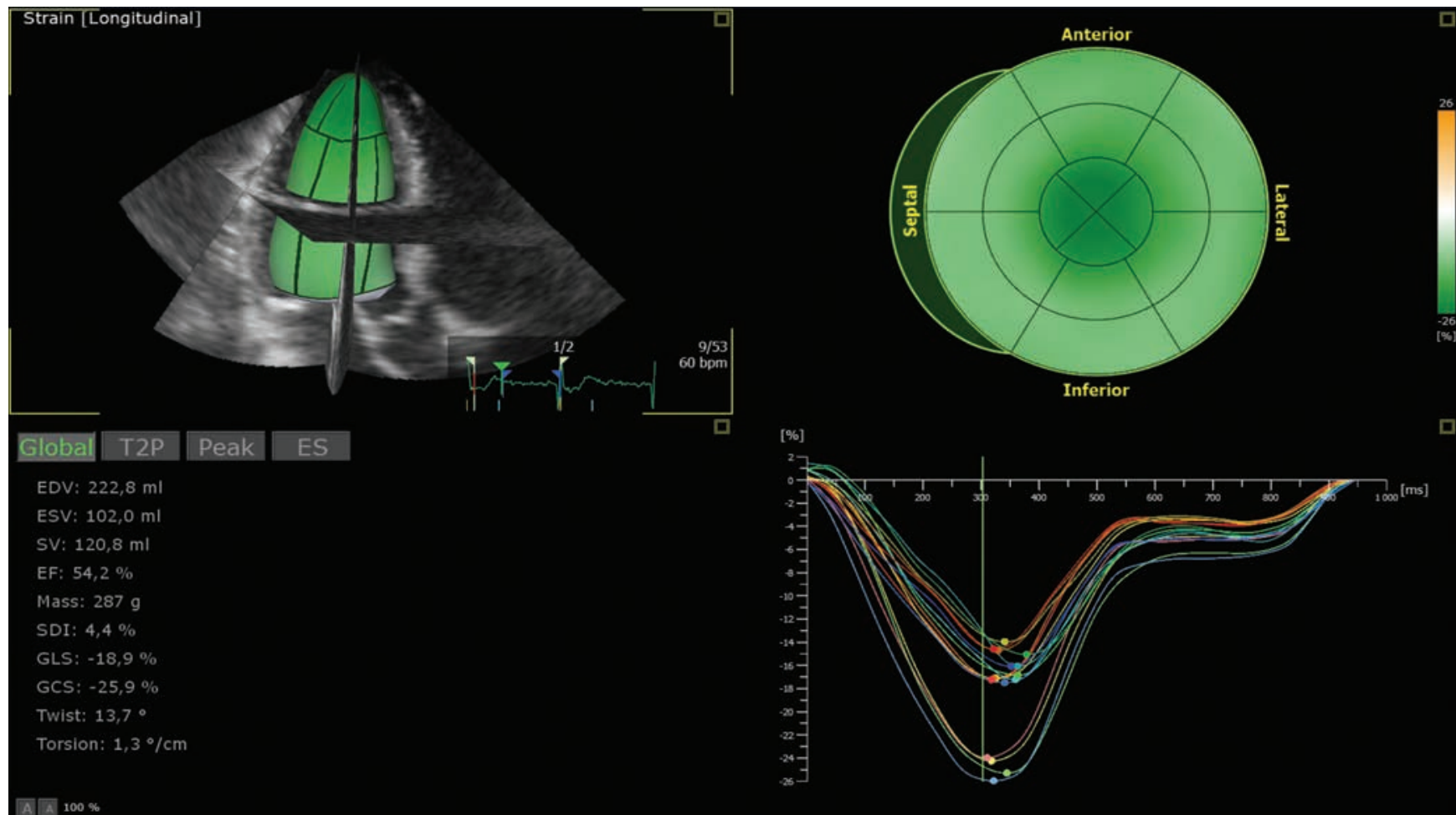

2. ÁBRA. bal kamrai 3D volumetriás és strain analízis egy reprezentatív sportolói példán. Bal oldalon a létrehozott bal kamrai „beutel” modell és az ebből derivált volumetriás és deformációs paraméterek értékei láthatók. Jobb oldalon a 16 bal kamrai szegmens „bull's eye” megjelenítése és idő-strain (longitudinális strain) görbéi láthatók 
3. TÁBLÁZAT. A sportolói és a kontrollcsoport 3D echokardiográfiás paramétereinek összehasonlítása

\begin{tabular}{|c|c|c|c|}
\hline & $\begin{array}{c}\text { Sportoló } \\
(n=11)\end{array}$ & $\begin{array}{c}\text { Kontroll } \\
(n=10)\end{array}$ & $\mathbf{p}$ \\
\hline LVEDV (ml) & $197 \pm 31$ & $135 \pm 26$ & $<0,001$ \\
\hline LVEDVi $\left(\mathrm{ml} / \mathrm{m}^{2}\right)$ & $98 \pm 16$ & $66 \pm 6$ & $<0,001$ \\
\hline LVESV (ml) & $89 \pm 16$ & $51 \pm 16$ & $<0,001$ \\
\hline LVESVi $\left(\mathrm{ml} / \mathrm{m}^{2}\right)$ & $44 \pm 8$ & $25 \pm 5$ & $<0,001$ \\
\hline LVSV (ml) & $108 \pm 17$ & $84 \pm 14$ & 0,003 \\
\hline LVSVi $\left(\mathrm{ml} / \mathrm{m}^{2}\right)$ & $54 \pm 9$ & $41 \pm 4$ & $<0,001$ \\
\hline LVEF (\%) & $55 \pm 4$ & $63 \pm 5$ & $<0,001$ \\
\hline LVM (g) & $240 \pm 45$ & $140 \pm 23$ & $<0,001$ \\
\hline LVMi $\left(\mathrm{g} / \mathrm{m}^{2}\right)$ & $119 \pm 24$ & $69 \pm 8$ & $<0,001$ \\
\hline LVGLS (\%) & $-17,9 \pm 1,6$ & $-22,1 \pm 3,0$ & $<0,001$ \\
\hline LVGCS (\%) & $-25,9 \pm 2,6$ & $-29,6 \pm 3,5$ & 0,012 \\
\hline RVEDV (ml) & $207 \pm 41$ & $131 \pm 20$ & $<0,001$ \\
\hline RVEDVi (ml/m²) & $103 \pm 19$ & $65 \pm 9$ & $<0,001$ \\
\hline RVESV (ml) & $102 \pm 24$ & $54 \pm 11$ & $<0,001$ \\
\hline RVESVi (ml/m²) & $50 \pm 11$ & $27 \pm 4$ & $<0,001$ \\
\hline RVSV (ml) & $106 \pm 19$ & $78 \pm 14$ & $<0,001$ \\
\hline RVSVi $\left(\mathrm{ml} / \mathrm{m}^{2}\right)$ & $53 \pm 10$ & $39 \pm 7$ & 0,001 \\
\hline RVEF (\%) & $51 \pm 3,1$ & $59 \pm 5$ & $<0,001$ \\
\hline FAC (\%) & $50,8 \pm 6,5$ & $55,3 \pm 10,9$ & 0,281 \\
\hline RV szeptális LS (\%) & $-19,7 \pm 3,7$ & $-25,4 \pm 4,0$ & 0,005 \\
\hline RV szabad fali LS (\%) & $-29,6 \pm 3,3$ & $-33,2 \pm 3,7$ & 0,039 \\
\hline
\end{tabular}

LV: bal kamrai, RV: jobb kamrai, „i”: testfelszínre indexálva, EDV: végdiasztolés volumen, ESV: végszisztolés volumen, SV: verővolumen, EF: ejekciós frakció, „M”: izomtömeg, LS: longitudinális strain, „C”: cirkumferenciális, „G”: globális, FAC: fractional area change

Megállapítható, hogy mind a bal, mind a jobb kamrára vonatkozóan jelentősen nagyobb volumenek mérhetök. Ezzel párhuzamosan mindkét kamra ejekciós frakciója kisebb egészséges, nem sportoló önkéntesekkel öszszehasonlítva, amely szintén igaz a kamrák longitudinális strain értékeire is. $A$ jelentős, a relatív falvastagság alapján koncentrikus típusú bal kamrai hipertrófia jelenléte mind hagyományos, mind $3 \mathrm{D}$ mérés alapján egyértelmü, az abszolút értékek között viszont jelentős különbség mutatkozik (a Devereux-formula túlbecsül). Mindezen eltérések felhívják a figyelmet a fejlett echokardiográfiás módszerek hasznára élsportolók kardiológiai szürésében és utánkövetésében egyaránt.

Az eddigi sportkardiológiai kutatások legtöbbje a bal kamra rendszeres edzéssel kapcsolatos változásait vizsgálta. Ennek oka egyrészről, hogy a szív ezen része a szisztémás keringés motorjaként közvetlenül felelős a terheléssel összefüggő keringési szükséglet biztosításáért, másrészről pedig a bal kamra felépítésében és müködésében mutatkoznak a legmarkánsabb változások a normál populációhoz viszonyítva. A korábban már említett elméletet (2), amely összefüggést állít a terhelés minősége és a morfológiai változások kö- zött, több nagy esetszámú vizsgálat részlegesen igazolta $(10,11)$, ám a sportspecifikus balkamra-hipertrófia és dilatáció megléte nem teljesen megalapozott, lévén mind a statikus, mind a dinamikus terhelésü csoport mutathatja egymás sajátosságait $(12,13)$.

A legtöbb sportágban változó mértékben keveredik a statikus és dinamikus komponens mértéke, így a szív morfológiai és funkcionális jellegzetességeinek széles skálája észlelhető (14). A sportágak terhelési sajátosságok szerinti beosztása széles körben elfogadott módszer, és durva becslést adhat az adott sportolónál várható fiziológiás remodelláció sajátosságaival kapcsolatban. Ezen jelenségek a terhelés mennyiségétöl függően egy folyamatos spektrumot képeznek, a hobbisportolók egyénhez mért változásaitól kezdve az olimpikonok normál populációhoz viszonyítottan is kifejezett sajátosságaival bezáróan (15). Vizsgálatunkban egyazon terhelési csoportba tartozó sportolókat vizsgáltunk, azonban a különböző versenytávok különböző edzésmunkát is igényelnek, így akár még ezen szük elit sem tekinthető tökéletesen homogén populációnak. Éppen ez teszi nehézzé a sportszív globális értelmezését, akár a sportolói normálértékek meghatározását: azonos nemú, azonos életkorú, azonos edzésmunkát végző (és hasonlóan jól is teljesítő) sportolókból nagy esetszámot vizsgálni és az ő eredményeikből a sportszív, mint általános fogalom jellegzetességeire következtetéseket levonni több mint problémás. Kajak-kenus élsportolóinkban - noha terhelésükben jelentős a dinamikus komponens is - koncentrikus típusú balkamra-hipertrófiát mutattunk ki. Irodalmi adatok alapján ismert, hogy a 3D echokardiográfiával meghatározott bal kamrai izomtömeg jóval szorosabb korrelációt mutat a gold standard szív MR-vizsgálattal, a Devereux-formula pedig túlbecsül (16). Élsportolói populációnk eredményei szintén ez utóbbira engednek következtetni, amely felhívja a figyelmet a 3D technika hasznára az izomtömeg mérése esetén is.

A bal kamra rendszeres fizikai terheléssel kapcsolatos funkcionális változásait szintén számos kutatás vizsgálta. Ezeket figyelembe véve általánosságban kijelenthető, hogy a sportolók megtartott nyugalmi ejekciós frakcióval rendelkeznek, ám egy nem elhanyagolható hányaduknál akár enyhén csökkent értékek is mérhetők (17). Jelen vizsgálatunk eredményei ezzel összevágnak. A szívizomzat funkciójának újabb vizsgáló módszerei hasonló eredményeket adnak, kétdimenziós speckle-tracking analízissel az atléták a kontrollhoz viszonyítva alacsonyabb longitudinális strain értékeket mutathatnak (18). Mindezen jellegzetességek feltehetően elsősorban a bal kamrai geometria változásainak következményei, lévén a megnövekedett végdiasztolés volumenek folytán a szív még alacsonyabb nyugalmi szívfrekvencia mellett is képes az adekvát perifériás perfúzió biztosítására, amit a normál populációhoz mérten jelentősen emelkedett nyugalmi verőtérfogat is igazol (11). Mindazonáltal a strain értékek csökkent 


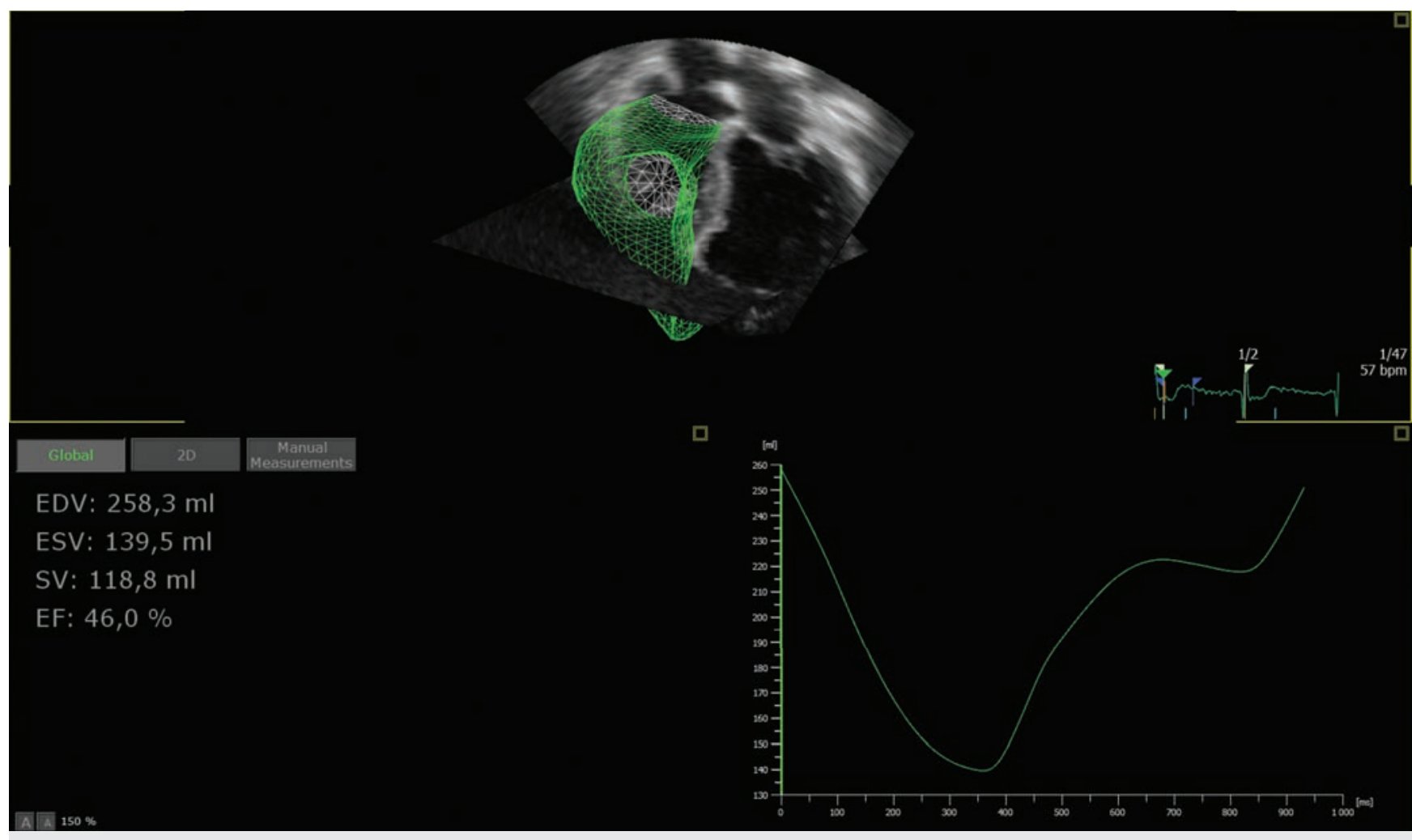

3. ÁBRA. Jobb kamrai 3D volumetriás analízis egy reprezentatív sportolói példán. Felül a létrehozott jobb kamrai „mesh" modell, alul az ebből derivált volumetriás értékek és a jobb kamrai idő-térfogat görbe látható

volta sportolókban megnehezíti a speckle-tracking technika használatát a sportszívvel átfedő patológiás állapotok felismerésében. Terhelés során a vártnak megfelelően szupranormális szisztolés funkcióról számol be az irodalom, ezen megnövekedett teljesítmény strain analízissel is igazolt (19). A sportszív állatkísérletes modelljén is kimutatták a strain paraméterek és az invazív nyomás-térfogat analízissel mért kontraktilitás közötti szoros korrelációt (20). Mindezek a sportszív miokardiális mechanikájának további, több komponenst is számításba vevő vizsgálatára sarkallnak, amelyeket komplexen megértve és alkalmazva, lehetővé válhat a patológiás esetek felismerése $(21,22)$.

Terhelés hatására azonban a jobb kamra esetén is fellép remodelling: dinamikus terhelésű sportágak esetén ismert a bal kamra tágulatával gyakorlatilag párhuzamos jobb kamrai dilatáció $(3,4)$. Ezeket a vizsgálatokat erősítik meg jelen eredményeink is. A statikus terhelés esetén az eredmények ellentmondásosak $(3,23)$, ám az erőnléti sportágakban, ahol a bal kamra, mint szisztémás nyomásgenerátor a teljesítmény kulcseleme, a jobb kamra szerepe alárendeltebb jelentőségü lehet.

Funkció tekintetében mind a globális, mind a regionális szisztolés működés a bal kamrához hasonló változásokat mutat irodalmi adatok alapján: a normál tartomány alsó felében, vagy enyhén csökkent ejekciós frakciót találunk, ezen felül a nem sportoló egészséges kontrollhoz viszonyítva alacsonyabb longitudinális strain értékek mérhetők
$(24,25)$. A legmodernebb, 3D echokardiográfiás megközelítésünk szintén ezt igazolta, hiszen az egészséges kontrollszemélyekhez képest nem csupán a jobb kamrai ejekciós frakció volt kisebb, hanem mind a szeptális, mind a szabad fali longitudinális strain csökkent értékeket mutatott. Mindezen változások a bal kamrához hasonlatosan a geometriai változásoknak tudhatók be, amelyet megerősítenek a terhelés hatására létrejövő változások a kontraktilitás tekintetében (25). Érdekes kérdés továbbá, hogy számos jobb kamrai nyomás és/vagy térfogatterheléssel járó patológiás állapothoz hasonlóan, van-e eltolódás a jobb kamra longitudinális és radiális (ún. fújtató) komponenseinek relatív arányában (26). Ez utóbbi mozgásirány jelentőségét a hagyományos echokardiográfiás paraméterek gyakorlatilag nem mérik (27), noha teoretikusan akár segítséget jelenthet az edzés indukálta jobbkamra-diszfunkció kimutatásában is.

\section{Limitációk}

Vizsgálatunk egyértelmü limitációja az alacsony esetszám. Kiemelendő értéket képviselnek azonban a vizsgált sportolóink, akik kétség kívül a világelithez tartoznak, a realitásokhoz mérten azonos típusú edzésmunkát folytattak és felkészülésüknek is azonos stádiumában vizsgáltuk őket. Ugyan a 3D echokardiográfia irodalmi adatok alapján közelíti a szív MR pontosságát a bal- és jobb kamrai volumetria, illetve a bal kamrai izomtömeg meghatározását illetően, valódi gold standard vizsgálat- 
nak azonban továbbra is ez utóbbi tekinthető. Vizsgálataink csak nyugalmi paraméterek elemzésére terjedtek ki, amelyek csak egy kis részét fedik fel a sportszív tulajdonságainak. Köztudottan a sportszív nyugalomban „tartalékol”. Terhelésre a sportoló szíve nagy pulzustartaléka és igen jó relaxációs képessége révén jelentős verővolumen növelésre képes. Valódi teljesítményét tehát a sportszív terhelésre adja le, így későbbi céljaink között szerepel a jelen kutatásunkban használt paraméterek változásának vizsgálata terhelés hatására.

\section{Következtetések}

Kajakos és kenus élsportolókban jelentős bal- és jobb kamrai dilatáció figyelhető meg. A bal kamrai izomtömeg is jelentősen emelkedett, koncentrikus balkamra-hipertrófiát eredményezve. A nyugalmi bal és jobbkamra-funkció, mind ejekciós frakció, mind longitudinális strain tekintetében megtartott, azonban nem sportoló egészséges személyekhez képest csökkent. További vizsgálatok szükségesek a terhelés-élettani geometriai és funkcionális változások mélyebb megértéséhez, amelyben azonban a 3D echokardiográfia értékes segítséget nyújthat.

\section{Irodalom}

1. Prior DL and La Gerche A. The athlete's heart. Heart 2012; 98 : 947-55. doi: 10.1136/heartjnl-2011-301329

2. Morganroth J, Maron BJ, Henry WL, Epstein SE. Comparative left ventricular dimensions in trained athletes. Ann Intern Med 1975; 82: 521-4. doi: 10.1.1.1024.7587 (?)

3. Pagourelias ED, Kouidi E, Efthimiadis GK, et al. Right atrial and ventricular adaptations to training in male Caucasian athletes: an echocardiographic study. J Am Soc Echocardiogr 2013; 26: 1344-52. doi: 10.1016/j.echo.2013.07.019

4. Major Z, Csajagi E, Kneffel Z, et al. Comparison of left and right ventricular adaptation in endurance-trained male athletes. Acta Physiol Hung 2015; 102: 23-33. doi: 10.1556/APhysiol.102.2015.1.2 5. La Gerche A, Claessen G, Dymarkowski S, et al. Exercise-induced right ventricular dysfunction is associated with ventricular arrhythmias in endurance athletes. Eur Heart J 2015; 36: 1998-2010. doi: 10.1093/eurheartj/ehv202

6. Mosteller RD. Simplified calculation of body-surface area. N Engl J Med 1987; 317: 1098. doi: 10.1056/NEJM198710223171717

7. Lang RM, Badano LP, Mor-Avi V, et al. Recommendations for cardiac chamber quantification by echocardiography in adults: an update from the American Society of Echocardiography and the European Association of Cardiovascular Imaging. Eur Heart J Cardiovasc Imaging 2015; 16: 233-70. doi: 10.1016/j.echo.2014.10.003

8. Devereux RB, Reichek N. Echocardiographic determination of left ventricular mass in man. Anatomic validation of the method. Circulation 1977; 55: 613-8. doi: 10.1161/01.CIR.55.4.613

9. Lancellotti P, Tribouilloy C, Hagendorff A, et al. and Scientific Document Committee of the European Association of Cardiovascular I. Recommendations for the echocardiographic assessment of native valvular regurgitation: an executive summary from the European Association of Cardiovascular Imaging. Eur Heart J Cardiovasc Imaging 2013; 14: 611-44. doi: 10.1093/ehjci/jet105

10. Pelliccia A, Culasso F, Di Paolo FM, Maron BJ. Physiologic left ventricular cavity dilatation in elite athletes. Ann Intern Med 1999; 130: 23-31. doi: 10.7326/0003-4819-130-1-199901050-00005 11. Baggish AL, Wang F, Weiner RB, et al. Training-specific changes in cardiac structure and function: a prospective and longitudinal assessment of competitive athletes. J Appl Physiol (1985). 2008; 104:

\section{1-8. doi: 10.1152/japplphysiol.01170.2007}

12. Roy A, Doyon M, Dumesnil JG, Jobin J, Landry F. Endurance vs. strength training: comparison of cardiac structures using normal predicted values. J Appl Physiol (1985). 1988; 64: 2552-7. doi: 10.1152/ jappl.1988.64.6.2552

13. Pluim BM, Zwinderman AH, van der Laarse A, der Wall EE. The athlete's heart. A meta-analysis of cardiac structure and function. Circulation 2000; 101: 336-44. doi: 10.1161/01.CIR.101.3.336

14. Levine BD, Baggish AL, Kovacs RJ, et al. Eligibility and Disqualification Recommendations for Competitive Athletes With Cardiovascular Abnormalities: Task Force 1: Classification of Sports: Dynamic, Static, and Impact: A Scientific Statement From the American Heart Association and American College of Cardiology. J Am Coll Cardiol 2015; 66: 2350-2355. doi: 10.1161/CIR.0000000000000237 15. Weiner RB, DeLuca JR, Wang F, et al. Exercise-Induced Left Ventricular Remodeling Among Competitive Athletes: A Phasic Phenomenon. Circ Cardiovasc Imaging 2015; 8. doi: 10.1161/CIRCIMAGING.115.003651

16. Kusunose K, Kwon DH, Motoki H, Flamm SD, Marwick TH. Comparison of three-dimensional echocardiographic findings to those of magnetic resonance imaging for determination of left ventricular mass in patients with ischemic and non-ischemic cardiomyopathy. Am J Cardiol 2013; 112: 604-11. doi: 10.1016/j.amjcard.2013.04.028 17. Abergel E, Chatellier G, Hagege AA, et al. Serial left ventricular adaptations in world-class professional cyclists: implications for disease screening and follow-up. J Am Coll Cardiol 2004; 44: 144-9. doi: 10.1016/j.jacc.2004.02.057

18. Richand V, Lafitte $S$, Reant $P$, et al. An ultrasound speckle tracking (two-dimensional strain) analysis of myocardial deformation in professional soccer players compared with healthy subjects and hypertrophic cardiomyopathy. Am J Cardiol 2007; 100: 128-32. doi: 10.1016/j.amjcard.2007.02.063

19. Baggish AL, Yared K, Wang F, et al. The impact of endurance exercise training on left ventricular systolic mechanics. Am J Physiol Heart Circ Physiol 2008; 295: H1109-H1116. doi: 10.1152/ajpheart.00395.2008

20. Kovacs A, Olah A, Lux A, et al. Strain and strain rate by speckle-tracking echocardiography correlate with pressure-volume loop-derived contractility indices in a rat model of athlete's heart. Am J Physiol Heart Circ Physiol 2015; 308: H743-8. doi: 10.1152/ ajpheart.00828.2014

21. Kovacs A, Apor A, Nagy A, et al. Left ventricular untwisting in athlete's heart: key role in early diastolic filling? Int J Sports Med 2014; 35: 259-64.

22. Szauder I, Kovacs A, Pavlik G. Comparison of left ventricular mechanics in runners versus bodybuilders using speckle tracking echocardiography. Cardiovasc Ultrasound 2015; 13: 7. doi: 10.1186/ s12947-015-0002-y

23. Perseghin G, De Cobelli F, Esposito A, ezt al. Effect of the sporting discipline on the right and left ventricular morphology and function of elite male track runners: a magnetic resonance imaging and phosphorus 31 spectroscopy study. Am Heart J 2007; 154: 937-42. doi: 10.1016/j.ahj.2007.06.039

24. Prakken NH, Velthuis BK, Teske AJ, et al. Cardiac MRI reference values for athletes and nonathletes corrected for body surface area, training hours/week and sex. Eur J Cardiovasc Prev Rehabil 2010; 17: 198-203. doi: 10.1097/HJR.0b013e3283347fdb

25. La Gerche A, Burns AT, D'Hooge J, et al. Exercise strain rate imaging demonstrates normal right ventricular contractile reserve and clarifies ambiguous resting measures in endurance athletes. J Am Soc Echocardiogr 2012; 25: 253-262 e1. doi 10.1016/j. echo.2011.11.023

26. Moceri $P$, Duchateau N, Baudouy $D$, et al. Three-dimensional right-ventricular regional deformation and survival in pulmonary hypertension. Eur Heart J Cardiovasc Imaging 2017. doi: 10.1093/ehjci/jex163 27. Lakatos B, Toser Z, Tokodi M, et al. Quantification of the relative contribution of the different right ventricular wall motion components to right ventricular ejection fraction: the ReVISION method. Cardiovasc Ultrasound 2017; 15: 8. doi: 10.1186/s12947-017-0100-0 